Florida International University FIU Digital Commons

$11-15-2006$

\title{
Artificially induced aggregation of fauna and their effects on nutrient regimes and primary producers in an oligotrophic subtropical estuary
}

Bryan M. Dewsbury

Florida International University

DOI: $10.25148 /$ etd.FI14062256

Follow this and additional works at: https://digitalcommons.fiu.edu/etd

Part of the Biology Commons

\section{Recommended Citation}

Dewsbury, Bryan M., "Artificially induced aggregation of fauna and their effects on nutrient regimes and primary producers in an oligotrophic subtropical estuary" (2006). FIU Electronic Theses and Dissertations. 2786.

https://digitalcommons.fiu.edu/etd/2786 


\title{
FLORIDA INTERNATIONAL UNIVERSITY
}

Miami, Florida

\begin{abstract}
ARTIFICIALLY INDUCED AGGREGATION OF FAUNA AND THEIR EFFECTS ON NUTRIENT REGIMES AND PRIMARY PRODUCERS IN AN OLIGOTROPHIC SUBTROPICAL ESTUARY
\end{abstract}

\author{
A thesis submitted in partial fulfillment of the \\ requirements for the degree of \\ MASTER OF SCIENCE \\ in \\ BIOLOGY \\ by
}

Bryan M. Dewsbury

2006 
To: Interim Dean Mark Szuchman

College of Arts and Sciences

This thesis, written by Bryan M. Dewsbury, and entitled Artificially Induced Aggregation of Fauna and Their Effects on Nutrient Regimes and Primary Producers in an Oligotrophic Subtropical Estuary, having been approved in respect to style and intellectual content, is referred to you for judgment.

We have read this thesis and recommend that it be approved.

Joel C. Trexler

Mike B. Robblee

James W. Fourqurean, Major Protessor

Date of Defense: November 15, 2006

The thesis of Bryan M. Dewsbury is approved.

Interìm Dean Mark Szuchman College of Arts and Sciences

Dean George Walker University Graduate School

Florida International University, 2006 


\begin{abstract}
OF THE THESIS
ARTIFICIALLY INDUCED AGGREGATION OF FAUNA AND THEIR EFFECTS ON NUTRIENT REGIMES AND PRIMARY PRODUCERS IN AN OLIGOTROPHIC SUBTROPICAL ESTUARY

by
\end{abstract}

Bryan M. Dewsbury

Florida International University, 2006

Miami, Florida

Professor James W. Fourqurean, Major Professor

In order to investigate the role of faunal aggregations in concentrating nutrients in the oligotrophic landscape of Florida Bay, I manipulated faunal densities in Florida Bay seagrass beds by constructing artificial reefs. The effects of reefs and faunal aggregations on nutrient availability and benthic community structure were assessed.

Over a year-long sampling period, artificial reefs had an average population of 50 fishes and crustaceans of various species. Faunal aggregation resulted in significant sediment organic matter decreases and sediment phosphorus increases. Plots with high fauna populations also had shorter seagrass blades presumably due to the effects of grazing. Chlorophyll- $a$ concentrations in the sediment and periphyton samplers were mainly affected by reef presence or exclosure type and not due to the presence of aggregating fauna. Our results suggest that faunal aggregation may have more top-down effects on primary producers than bottom-up effects over smaller temporal scales. 


\section{TABLE OF CONTENTS}

CHAPTER

PAGE

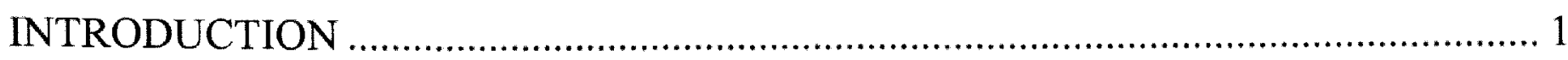

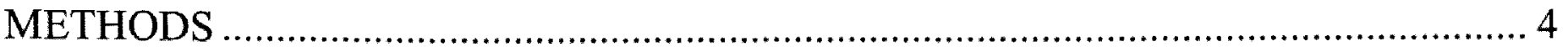

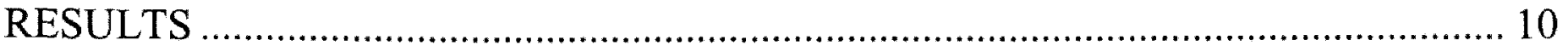

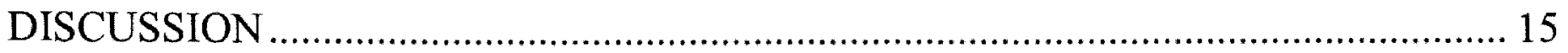

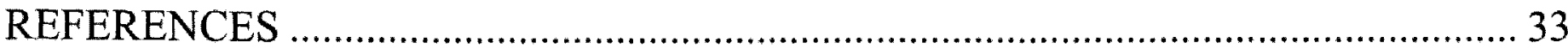




\section{LIST OF FIGURES}

FIGURE

PAGE

Figure 1. Map of central portion of Florida Bay with Florida state inset.................... 27

Figure 2. Layout of treatments and replicates in the field .................................. 28

Figure 3. Fish abundances for May 2006. Error bars represent standard error. ............ 29

Figure 4. Time series graph showing comparisons between reef and no reef treatments in organic matter, nitrogen and phosphorus concentration................................ 30

Figure 5. Nitrogen, phosphorus content and height comparisons of Thalassia between May 2005 and May 2006. Error bars represent standard error.

Figure 6. Time series graph comparisons of sediment chlorophyll- $a$ changes .............. 32 


\section{Introduction}

The effects of faunal aggregation have been documented extensively in the scientific literature, particularly effects on nutrient regimes (Kitchell et al. 1979, Wiegbert and Owen 1971). Examples of this aggregation and its subsequent effects on nutrient regimes abound in terrestrial systems. The effects on nutrient regimes include, but are not limited to herbivory (Day and Detling 1990, Frank and McNaughton 1992, Lock 1971), removal or accumulation of organic matter (Lal 1998), and nutrient deposition via defecation (Joblin 1981). Of these processes, defecation has been shown to produce greater changes in nutrient concentration in substrates and among primary producers. Quantification and analysis of the impact of concentrated animal feces has been recorded for such diverse animals such as colonial birds (Lindeboom 1984, Bildstein et al. 1992, Post et al. 1998, Powell et al. 1991, Hayes and Caslick 1984, Allaway and Ashford 1984, McColl and Burger 1976), herding bison (Day and Detling 1990, Frank and McNaughton 1992, Lock 1971) and nesting ants (Wagner 1997, Lugo et. al 1973, Frouz et al. 2002, Wagner and Jones 2004). Animal excreta have a high nutrient concentration; deposition of this excreta results in higher rates of primary productivity (Powell et al. 1991, Bosman et al. 1986). In marine systems however, faunal aggregations are often limited by lack of shelters such as reefs. Though there is evidence of considerable nutrient transfer when anadromous fishes swim upstream to spawn (Gende et al. 2002, Durbin et al. 1979), marine fauna aggregation effects on nutrient regimes are mostly associated with the habitation by fish of stationary objects such as coral reefs and artificial reefs, since these fish feed away from the reefs and return to the reefs for shelter where they defecate. Considerable amounts of research has been devoted to the role artificial reefs play in 
inducing fish aggregations (Bortone 2006), but reports on nutrient translocation by aggregating species is largely limited to rocky reef systems. Convincing evidence has been reported to support the theory that fishes, through diel feeding patterns and subsequent defecation, transport nutrients to the reef systems from the surrounding seagrass beds (Rothans and Miller 1991, Ogden and Ehrlich 1977, Meyer et al. 1983, Meyer and Schultz 1985). Fish feces, which is rich in nitrogen and phosphorus not only provide an enriched environment for coral species, but also serves as food for other members of the reef community (Youngbluth 1982).

Fecal addition by wading birds in seagrass beds have shown long-term changes in species composition and macrophyte morphometrics as a result of the feces deposition (Powell et al. 1991), but a similar effect has not been shown to occur from fish defecation. The aggregation of fauna due to the presence of reef does not only result in the 'bottom-up' effects associated with defecation, but also produces patterns associated with spatial preferences in grazing. Sea urchins (Diadema antillarum) produce a region of bare sediment (also called a 'halo') through intense feeding on macrophytes. This 'halo' has been observed in both natural and artificial reef units (Randall 1965, Ogden et al. 1973, Alevizon 2002).

The 'defecation effect' should be more pronounced in oligotrophic environments due to the nutrient limitation of primary producer biomass. Changes in background nutrient ratios in existing nutrient-limited environments can alleviate this oligotrophy, and lead to changes in the structure of the benthic community. Florida Bay is an oligotrophic phosphorus-limited subtropical estuary that supports a seagrass-dominated landscape (Figure 1) (Zieman et al. 1989, Fourqurean et al. 1992). Experimental manipulations 
using fecal deposition by piscivorous birds in Florida Bay demonstrated that seagrass biomass in Florida Bay is phosphorus limited, and bird feces addition resulted in significant sediment nutrient increases, as well as change in dominance from late successional Thalassia testudinum to faster growing, early successional Halodule wrightii (Powell et al. 1991, Fouqurean et al. 1995). Florida Bay is a system of discontinuous banks and mangrove islands (Zieman et al. 1989) with very little vertical reef to serve as refugia for fish away from mangrove prop roots. Thus, the aggregation of fish in the deeper areas ( $>1$ meter) of the Bay is rare due to reef limitation.

Using an artificial reef that followed the design of Davis' (1985) spiny lobster (Panulirus argus) habitat mitigation experiment, I conducted a year-long investigation of faunal aggregation and the effects of that aggregation on the benthic community near Bob Allen Keys ( $25^{\circ} 02.095^{\prime}$, W $\left.080^{\circ} 39.437^{\prime}\right)$. Building on existing evidence of thigmotaxism, defecation rates of fauna and nutrient limitation in Florida Bay, I seek to answer the question: can fish concentration significantly increase concentration of nitrogen and phosphorus in an oligotrophic system, and do such increases affect seagrass community that surround the faunal aggregation? I also examine the ecological consequences of this nutrient deposition as reflected by changes in benthic chlorophyll, filamentous algae, seagrass cover and seagrass nutrient content. To answer the question and address the consequences I tested the hypotheses that (1) the artificial reef will attract fauna from surrounding areas and (2) this increased concentration of fauna will result in (i) increased sediment $\mathrm{N}$ and $\mathrm{P}$, (ii) increased sediment organic matter, (iii) increased sediment chlorophyll, (iv) increased periphyton chlorophyll, (v) increased seagrass tissue 
concentration of $\mathrm{N}$ and $\mathrm{P}$, (vi) decreased macrophyte abundance close to reefs due to grazing and (vii) reduced seagrass height also due to the effects of grazing.

\section{Methods}

\section{Location}

Florida Bay is a semi-enclosed estuary bordered by the Gulf of Mexico to the west, the Everglades to the north and the Florida Keys to the east and south (Figure 1). The bay contains numerous tree islands and mud banks which act as discontinuous barriers to water flow through the region. Florida Bay is primarily fed by Taylor Slough (freshwater) and the Gulf of Mexico (marine water). Water temperatures in Florida Bay range from $16^{\circ} \mathrm{C}$ in the winter months increasing to $31^{\circ} \mathrm{C}$ in the late summer and early fall sampling periods. Salinities typically range from $27 \mathrm{ppt}$ to $38 \mathrm{ppt}$. In early summer customary freshwater inflows result in lower than average salinities of $17 \mathrm{ppt}$. Water turbidities range from $0.44 \mathrm{ntu}$ to $2.87 \mathrm{ntu}$ in especially turbid winter months.

Florida Bay supports one of the largest and most expansive seagrass beds in the world (Iverson and Bittaker, 1986). Thalassia testudinum is the dominant species of the 1660 $\mathrm{km}^{2}$ of seagrass beds present in the bay (Zieman et al. 1989). Syringodium filiforme can also be found but mainly in the western parts of the bay where marine influences are stronger (Zieman et al. 1989). Halodule wrightii is also common but does not have as large a standing crop as Thalassia testudinum (Zieman et al. 1989). Florida Bay is also home to a variety of species of juvenile and adult fauna (Thayer and Chester 1989). These fauna species (mostly juvenile) are primarily found in seagrass patches which they 
use as habitat, food source and protection. Thus Florida Bay, like other seagrass dominated estuaries around the world act as a nursery for many juvenile species of fauna that upon maturity migrate to the reef tract or to the Gulf of Mexico. This artificial habitat manipulation took place to the east of the Bob Allen Keys in the east-central region of Florida Bay (Zieman et al. 1989). It is characterized by salinities in the $30-45$ ppt range, low water-column and porewater nutrients (Fourqurean et al. 1992, Fourqurean et al. 1993) and sparse Thalassia testudinum beds. Halodule wrightii is present but is located primarily nearer the banks and is even more sparse or altogether absent at depths $>2$ meters.

The study site was chosen because seagrass species are sparse and because another artificial reef is located 'involuntarily' in the same area. A small plane wreck is located to the east of the Bob Allen Keys and is home to many fauna species including mangrove snappers (Lutjanus griseus), French grunts (Haemulon plumieri), pipefishes (Syngnathus floridae) and nurse sharks (Carcharias taurus)[personal observation]. Over the years the area surrounding the wreckage has developed into a relatively lush seagrass meadow of Thalassia testudinum and Halodule wrightii (JW Fourqurean, personal communication). The artificial reefs and corresponding controls used in this experiment are located in the same general area as the sunken aircraft. 


\section{Experimental Design}

To address the hypotheses laid out in this experiment a $2 \times 3$ factorial design was employed. There were 2 levels of reef (reef and no reef) and three levels of exclosure (no exclosure, partial exclosure and exclosure). The artificial reefs consisted of $140.2 \times 0.2 \times$ 0.4 meter concrete blocks arranged in a pyramid formation (Davis, 1985). This arrangement results in a reef that averaged 1.3 meters in width and length and 0.6 meters in height. The top of the reefs were approximately 1 meter below the mean water level. An exclosure was constructed to control for the possible effects (shading and sedimentation) that the reef itself may have on the sediment and seagrasses in the absence of fish aggregation. The exclosure consisted of 1.3 centimeter PVC tubing in a rectangular table frame with legs that were planted into the sediment. The PVC was cut to ensure that the length of the top of the exclosure was consistent with the top of the reef. Monofilament netting $(2.5 \mathrm{~cm}$ mesh) was then draped over and attached to the frame. To control for the possible effects the exclosures may have on sediment and seagrass, a treatment with the PVC frame only was constructed and referred to as partial exclosure. Each treatment (reef, reef with partial exclosure, reef with full exclosure, seagrass, seagrass with partial exclosure and seagrass with full exclosure) was replicated three times in the field and arranged randomly in three columns for a total of 18 plots (Figure 2).

Statistical analyses used to evaluate possible differences accounted for possible spatial differences between treatments as well as the effect of time on the response variable. A 2 $x 3$ ANOVA was used to investigate possible the effects of the presence of reefs and exclosures on seagrasses in Florida Bay. The two factors were Reef ( 2 levels - reef, no 
reef) and Exclosure (3 levels - no exclosure, partial exclosure, full exclosure). The experiment was tested for effects of each factor as well as within subject effects on the response variables. A Student-Newman-Keuls test was used to test for significant differences between treatments means to address specifically our hypothesis. A repeated measures procedure was employed to determine the effects of time on the increase or decrease of response variables. In the case of a significant interaction effect, the difference of least mean squares were used to calculate which treatments were significantly different. A two-way ANOVA was also used ( $3 \times 2$ factorial) to investigate possible differences in Thalassia nutrient concentrations. Thalassia percentage cover was analyzed using a Chi-squared distribution that assessed the relative independence of treatment levels to the frequency of macrophyte cover categories. All significant values are reported at the $5 \%$ level. Statistics programs were run using SAS (version 9.1.3.) manufactured by the SAS institute.

\section{Sampling}

Data collected from the treatments were all done on SCUBA. Sampling trips occurred every two months with the exception of January due to continuous bad weather and resulting poor visibility. To investigate the response of the variables outlined in the hypotheses the following procedures were employed. 
Faunal abundance: The abundance of fauna at each treatment was determined by visual assessment on SCUBA and corroborated with short digital underwater video camera. Special care was taken to not scare fauna away through excessively heavy breathing.

\section{Sediment nutrient concentration:}

Sediment samples were retrieved using piston cores made from $10 \mathrm{cc}$ syringes with the tips cut. Two cores were taken adjacent to the plot and two approximately 1 meter away. Sixteen cores were taken per plot. Eight of these cores were used for $\mathrm{N}$ and $\mathrm{P}$ analysis and the other 8 were used for sediment chlorophyll- $a$ determination. The top $5 \mathrm{cc}$ of the cores were then placed into a scintillation vial. The sample was dried and crushed into a fine powder. Sub-samples used for organic content analysis were taken from the same vials that provided sub-samples for $\mathrm{N}$ and $\mathrm{P}$. About $3 \mathrm{~g}$ of sample was measured in a preweighed aluminum dish. The dish plus contents were then weighed and subsequently ashed in a muffle furnace for 4 hours at $500^{\circ} \mathrm{C}$. The dish plus ashed contents were then weighed again. Percent organic matter was calculated by subtracting the final weight from the intial weight and calculating that figure as a percentage of the orginal sample amount. A sub-sample of approximately $5 \mathrm{mg}$ was weighed out from each vial for nitrogen. Carbon and Nitrogen content were then determined using a CHN Carlo-Erba Elemental Analyzer (FISONS NA1500). A sub-sample of 20-25 mg was used to determine phosphorus content. Phosphorus concentration was determined using a dry oxidation-acid hydrolysis extraction followed by a colorometric determination procedure (Fourqurean et al 1992b). 
Sediment Chlorophyll- $a$ : The vials with sediment samples destined for Chl- $a$ analysis were kept in the dark on ice in a sealed cooler until it was transferred into a freezer in the lab. The Chl- $a$ samples were freeze-dried in the dark for 4 days and $20 \mathrm{ml}$ of $90 \%$ acetone were added to each vial. The samples were allowed to sit for 4 days for complete extraction and a relative fluorescence determination procedure was followed (Southeast Environmental Research Center Standard Operating Procedure [SERC SOP] 10/28/98) to calculate Chl- $a$ concentration in the sample.

Periphyton Chlorophyll-a: To determine algal concentration a periphyton sampler was placed at each treatment. Each sampler was fitted with ten $25 \times 76 \mathrm{~mm}$ slides. At each sampling event the samplers were retrieved, placed on ice in a cooler and returned to the lab. Each slide from each sampler was scraped and separated by treatment. The scraped material was diluted to $40 \mathrm{ml}$. One $\mathrm{ml}$ of this mixture was extracted and run through a GF/F filter using a vacuum pump. The filtered material along with the filter were placed in a $2 \mathrm{ml}$ curvette, and stored in the dark. Twenty-four hours before Chl- $a$ analysis $3 \mathrm{ml}$ of acetone was added to each curvette. After 24 hrs Chl- $a$ concentration was determined using the same procedure as that used for sediment Chl- $a$ (SERC SOP 10/28/98).

Thalassia $\mathbf{N}$ and P: Seagrass samples were only taken twice for the duration of the sampling period (once at the beginning and at the end of the sampling period) so that continued destructive sampling would not interfere with macrophyte abundance estimates. Six seagrass shoots were taken per treatment and stored in a clear, labeled plastic bag on ice. Upon return to the lab the seagrass leaves were scraped for epiphyte 
removal, measured for length and width and stored in a pre-weighed, pre-labeled tare. The sample was placed in a drying oven at $70^{\circ} \mathrm{C}$ for 4 days. After drying, the tare and dried sample were weighed and dry weight of the sample calculated. The sample was then crushed using a mortar and pestle and placed in a $10 \mathrm{ml}$ vial where extracts were used to conduct nutrient analyses using the same procedures described for sediment samples.

Thalassia cover: The Braun Blanquet method for determining percent cover was adopted from Fourqurean et al. (1999) and was done using a 0.25 meter squared PVC quadrat. Percent cover was determined for each species within the quadrat and a score given to each species depending on what that percent was (Table 1). This assessment was performed twice adjacent to the plot and twice $0.5 \mathrm{~m}$ away on each side of the treatment.

Thalassia height: The height of seagrass shoots were measured while on SCUBA with $30 \mathrm{~cm}$ rulers. Three shoots were measured per quadrat sampled. Shoots were chosen at random in each quadrat. Height measurements were taken per quadrat and averaged per treatment plot.

\section{Results}

\section{Faunal Response}

Faunal data was log-transformed to meet the assumptions of normality. The presence of artificial reefs on average resulted in significant faunal aggregation at plots that 
contained them (ANOVA, reef main effect, $\mathrm{p}=<0.0001$, Table 2). Plots that contained exclosures on average contained less fauna due to the presence of the exclosure (ANOVA, exclosure main effect, $\mathrm{p}=<0.0001$ ). There was a significant interaction between reefs and the type of exclosure used (Table 3 ). Reefs with no exclosures and partial exclosures contained more fauna than all other plots (Table 3, reef x exclosure interaction, $\mathrm{p}<0.0001$ ). There was a significant effect of time on all plots (ANOVA time main effect, $p=0.0008$ ) and the changes of faunal abundance over time depended on the presence of an artificial reef (Table 3, reef $x$ time interaction, $p=0.0008$ ). The artificial reefs were placed at the experiment location in mid-March and by May, when the first sampling occurred, reefs and reefs with partial exclosure were already heavily populated by various fauna (Figure 3 ). In every month sampled, there was a significantly larger group of fauna at reefs and reefs with partial exclosure. Reefs and reefs with structure contained an average of 51 fishes and crustaceans of 8 different species. The dominant species present was the gray snapper (Lutjanus griseus). Schools of Atlantic Spadefish (Chaetodipterus faber) were abundant in the first two sampling periods but were not seen in appreciable numbers thereafter. Spiny lobsters (Panulirus argus) and Florida stone crabs (Menippe mercenaria) took refuge in the inner hollows of the concrete blocks. The exclosures were successful in excluding large fauna from using artificial reefs. Crustaceans were in general successfully excluded from occupying concrete blocks in reefs where full exclosures were present. Other species present in smaller numbers were the red grouper (Epinephelus morio), triggerfish (Balistes capriscus) and juvenile grunts (Haemulon spp). All fauna present were juveniles of their respective species, consistent with previous assessments of Florida Bay fauna. Reef fishes were generally observed to 
swim around the reefs and through the holes in the concrete blocks and did not appear to be interested in retreating even in the presence of a diver. There were approximately 3 lobsters and about 1 stone crab per reef.

\section{Sediment Organic Matter}

There was no effect of reef presence or exclosure type on percent organic matter (ANOVA, main effects Figure 4). There was an overall effect of time on all plots (ANOVA, time main effect, $\mathrm{p}<0.0001$ ) and the level of this effect also depended on the presence of a reef (Table 3 , reef $\mathrm{x}$ time interaction, $\mathrm{p}<0.0001$ ).

\section{Sediment Nitrogen}

There was no significant evidence to reject the null hypothesis that there was no increase in nitrogen concentration over time $(\mathrm{p}=0.406)$. There were also no effects of reef presence of exclosure type on nitrogen concentration (Table 2).

\section{Sediment Phosphorus}

There was a significant effect of reef presence (ANOVA, reef main effect $p=0.028$, Table 2) and exclosure type (ANOVA, exclosure main effect, $\mathrm{p}=0.020$ ) on sediment phosphorus concentration. Sediment phosphorus was lowest during May 2005, consistent with typical low phosphorus values for Florida Bay sediment, but showed significant increases in treatments with high fish abundances over the sampling period (Table 3, reef $\mathrm{x}$ exclosure $\mathrm{x}$ time interaction, $\mathrm{p}<0.0001$ ). The reef with partial exclosure treatment showed steady increase in percent phosphorus for every month sampled. Phosphorus concentration increased significantly with time at reef only and reef with partial exclosure 
treatments by the end of the sampling period $(\mathrm{p}=0.050)$. By May 2006 reef only treatments averaged $0.0089 \%$ phosphorus and reef with structure treatments averaged $0.0087 \%$ phosphorus. Phosphorus values fluctuated between treatments and over sampling months, but phosphorus concentrations were higher at the aforementioned treatments in the last two sampling months.

\section{Sediment Chl-a}

Sediment chlorophyll- $a$ concentrations fluctuated throughout the yearlong sampling but reached higher values in plots with reefs (ANOVA, reef main effect, $p=0.050$ ) compared to plots without reefs. During the months of July, September and November there seemed to be an uncharacteristic rise in chlorophyll- $a$ numbers for all treatments $\left(>400 \mathrm{ug} / \mathrm{m}^{2}\right)$, but sampling in the two months of 2006 yielded extremely low values.

\section{Periphyton Chl- $a$}

Chlorophyll- $a$ measured from periphyton samplers varied both spatially and temporally. There was a significant effect of time averaged across all treatments (ANOVA, time effect, $\mathrm{p}<0.001$, Table 2). Chlorophyll- $a$ concentrations also varied significantly with the type of exclosure present (ANOVA, exclosure main effect, $\mathrm{p}=0.0001)$. There were also differences in periphyton chlorophyll- $a$ also showed treatments with full exclosures having greater abundance than treatments with no exclosures and partial exclosures (Table 3, reef $x$ exclosure interaction, $\mathrm{p}=<0.0001$ ). Plots with full exclosures generally produced higher values that plots without them (Table 3, reef $\mathrm{x}$ exclosure $\mathrm{x}$ time interaction $\mathrm{p}<0.0001)$. Samplers were first put out during the May sampling event and asuch the first analyses were done on July samples. Hurricane events in south Florida resulted in the loss of periphyton samplers placed in July and therefore 
no data was recorded for September. New periphytometers were placed which represents the November collection. Periphytometers collected in March 2006 were placed in January 2006 such that data collected still represented a two-month time interval. For most sampling events, periphyton chlorophyll- $a$ was greatest at the treatments with full exclosures.

\section{Thalassia Nutrients}

Thalassia shoots at plots with artificial reefs had significant higher concentrations of nitrogen at the reef treatments compared to the non-reef treatments (ANOVA, reef main effects, $\mathrm{p}=0.012$ ) (Figure 4). Nitrogen concentrations in Thalassia ranged between $2.75 \%$ and $2.89 \%$ at the beginning of the sampling period. There were no changes in Thalassia phosphorus concentrations between the beginning and the end of the sampling period at any treatment and no differences were observed between treatments in May 2006.

\section{Thalassia cover}

There was no significant difference in Thalassia abundance between treatments $\left(X^{2}=20.023<31.410=X_{0.95}\right)$. In March 2006 a ‘halo' began to develop around reef, reef with reef as well as reef with exclosure treatments. In May 2006 the successional seagrass species Halodule wrightii began growing within the 'halo'. These new shoots were sparse and only covered $0-5 \%$ of the quadrat area.

\section{Thalassia height}

There was a significant difference however in height of seagrass shoots when measured from the sediment surface to the tip $(\mathrm{p}=0.000)$. This difference only occurred in March 2006 and May 2006 of the sampling period (Figure 6). Shoots around reef only 
and reef with partial exclosure treatments were shorter presumably due to the effect of grazing. Fish biting seagrass leaves was often witnessed while samples were being taken.

\section{Discussion}

Artificial reefs and artificial reefs with partial exclosures caused strong and consistent faunal aggregation over a year-long sampling period supporting my original hypothesis about the effect of structure. Artificial reefs containing full exclosures were successful at excluding fish from populating reefs. At the plots containing high abundances of fauna there were measurable changes in the nutrient regime as well as top-down effects attributable to the fauna present. There was a significant decrease of organic matter at plots containing fauna which was considerably different to what I expected. There was a significant increase of phosphorus content of the sediment at reefs over the year. I did not see the expected change in nitrogen concentrations in the sediment as it remained stable throughout the sampling period. Chlorophyll- $a$ measured in periphytometers were greater at plots containing full exclosures as opposed to plots with high faunal abundance as I

predicted. Sediment chlorophyll- $a$ was higher at all reef plots and not only where there were aggregations of fauna. Thalassia nitrogen increased at reef plots but phosphorus remained similar for all plots. There was strong evidence to support my top-down hypothesis as I saw strong grazing effects on Thalassia as reflected by decreases in Thalassia height at plots with high abundances. 
The response of the animal community is not completely surprising as the literature abounds with many examples of this phenomenon (e.g. Kitchell et al. 1979). The magnitude and speed of the faunal response to the presence of these reefs however was comparable to other small scale experiments of this nature carried out near systems with known higher abundances. Reefs were placed near Bob Allen Keys in mid-March and were teeming with high abundances of fauna by early May. Fauna were virtually absent (with one or two exceptions) from reefs with exclosure and all plots with no reefs. Fishes present were mostly juveniles. In later sampling months (March and May 2006), fishes were visibly larger, but since no sampling mechanism was setup to assess this, I cannot report with certainty the apparent change in average size. The faunal response to reefs at Bob Allen Keys thus supports studies from other different but related experiments (Alevizon 2002) on artificial reefs as attractants to fauna (Stone et al. 1979, Randall 1963). It especially corroborates evidence brought forward by Davis (1985) on the use of artificial reefs in the design used here, as mitigation for juvenile lobster habitat as there was a consistent presence of spiny lobsters in the reefs on every sampling event.

I did not detect organic matter increases attributable to faunal defecation at these reefs over a temporal scale of one year probably for three reasons. First, areas of seagrass growth in Florida Bay generally have high organic matter loading rates due to the presence of dead short shoots that form mats around live plants (Gallagher et al. 1984). The high residence time of Florida Bay waters means that organic matter will accumulate (Fourqurean and Zieman, 1992). Furthermore, Florida Bay is a system of discontinuous banks and mangrove islands (Fourqurean and Robblee 1999). One of these banks lie about 100 meters to the south of the experiment location further exacerbating the 'basin 
effect' of trapping organic matter in the area before it. Secondly, the organic matter loading rate of marine fauna is very low, especially when compared to that of piscivorous birds, whose guano was used to perform a similar manipulation in Florida Bay (Powell et al. 1991). Piscivorous birds release 2-4g of excrement per day (Powell et al. 1991). Thirdly, the reefs and exclosure mechanisms also act as trapping objects. Mobile organic matter was trapped behind cinderblocks and was sometimes caught in the monofilament. Continuous replacement and cleaning of the monofilament cages may not necessarily have been enough to completely alleviate the effect of this trapping. These and other factors would have made our prediction of higher organic matter concentrations difficult to detect. What I did discover however was almost the complete opposite. Treatments with strong faunal abundances yielded significantly lower organic matter concentrations, in spite of high existing levels of organic matter in this area and ongoing faunal defecation. There are a number of factors that may have contributed to this phenomenon. The 'halo effect' in the later months of sampling presents an area with lower seagrass cover and subsequently lower organic matter from seagrass. Also, reefs without exclosures were also populated by large amounts of bivalves (personal observation), not seen in similar abundances at any of the other treatments. These filter feeders along with other nondescript organisms may have played a role in removing organic matter from the system. Faunal presence, increased organic matter and changes in the primary producer community may have also resulted in increases in microbial processes that can result in the breakdown and subsequent removal of organic matter. Mineralization of organic matter is nutrient-limited and nutrient addition may have increased decomposition of organic matter. 
Variations (or lack thereof) in sediment concentrations of nitrogen and phosphorus may be related to the nutrient limitation that affects Florida Bay as a whole (Powell et al. 1989) and may not be solely due to defecation. The increases I saw in phosphorus concentration and lack of change in nitrogen concentration may be related to phosphorus limitation and nitrogen saturation in Florida Bay. While this experiment does not in itself provide evidence of nutrient limitation, previous manipulations involving piscivorous birds allows us to make suppositions based on phosphorus limitation (Fourqurean et al. 1992). The largest phosphorus source for Florida Bay is the Gulf of Mexico with very little coming in from Everglades slough runoff (Fourqurean et al. 1992). The location of this phosphorus source means that there is a gradation of this limitation from the easterly to the westerly portions of the Bay (Powell et al. 1989). Bob Allen is located in central Florida Bay where strong limitation exists (Armitage et al. 2006). Nitrogen is not a limiting nutrient and is present in saturation. The 3-month water residence time of Florida Bay means that there is a net buildup of nitrogen derived primarily from bacterial processes. Further addition of nitrogen through excretion may not be in quantities large enough to detect significant increases in concentration. In the relatively short duration of my experiments however, phosphorus is present in small quantities. Small additions of phosphorus will therefore be more easily detectable. The phosphorus increases at reefs adds to the body of evidence of phosphorus limitation in Florida Bay, where in this case marine fauna provide the alleviating nutrient. I can ascertain this by the fact that complementary increases were not observed at treatments where there weren't high fish abundances. 
Significant changes in sediment chlorophyll- $a$ due to reef presence may simply be due to accumulation of benthic microalgae around reefs. Periphyton Chl- $a$ concentrations were higher at treatments with exclosures largely because the monofilament netting used trapped seagrass leaves and itself contained algal growth. Even with consistent cleaning and removal, it is highly likely that trapped material is responsible for the significant increases in Chl- $a$ values at these treatments.

The time scale of this experiment was probably too short to observe any significant uptake of phosphorus in the seagrass tissue surrounding the reef, considering that the previously discusses bird experiment with higher loading rates required multiple years for changes to be seen. The factors that have resulted in nitrogen concentration increase in seagrass tissue at reef treatments remain unclear, especially since a similar pattern was not observed in sediment nitrogen concentration. A longer time period may be needed to properly elucidate this effect. Loading rates and time scales may also be the main factor in the unchanging seagrass beds surrounding reefs and controls (Ogden and Ebersole, 1981). In the last sampling event however, the growth of new shoots of shoalgrass Halodule wrightii was observed in the 'halo' (Randall 1965) around one of the reef only treatments. Shoalgrass, a successional species which has a selective advantage in high nutrient environments (Powell et al. 1991) commonly appears when blowouts occur or over mounds. The presence of this species is an indication of the beginning of a possible shift in species composition, but the completion of such a change can only take place over much larger temporal scales.

I saw strong top-down effects of herbivory that may do more to shape the primary producer community than nutrient addition at these sites over smaller temporal scales. 
The strong grazing effect at the reefs with high fish populations was a phenomenon that was seen by divers during sampling events. Trigger fish and grunts were seen snipping at the seagrass blades, the algae on the reef itself and the growth on the periphytometers. This action indicates that the effects on seagrass height may not be solely due to herbivorous fish but may also be due to grazers that feed on epiphytic organisms that dwell on seagrass blades. I attribute the strong significant differences in seagrass height between the reef, reef with partial exclosure and all others to this grazing effect that may have extended well beyond the distance sampled. It would be premature to completely blame reduced seagrass coverage around fauna populated treatments to the grazing effects as the sedimentation around reefs, blowouts from inclement weather may also have played roles in the 'halo effect'.

The effect fish and invertebrate aggregations have on coral reefs and their immediate environs have been reported on at length. I present evidence here that faunal aggregations impact seagrass meadows in oligotrophic estuarine waters. I report significant increases in sediment phosphorus that is directly attributed to the aggregation of fish around these reefs as evidenced by the lack of a similar increase in corresponding controls. The consequences of faunal aggregation are not limited to nutrient concentration and in this manipulation I witnessed measurable top-down effects of herbivory on both seagrass and algal species. This short-term experiment not only underscores the grouping nature of marine fauna in an estuarine environment, but also shows that the bottom-up effects of this grouping are largely determined by the existing state of nutrient limitation. Nutrient cycling in terrestrial systems as affected by faunal movement and aggregation is wellstudied (Joblin 1981, Hayes and Caslick, 1984, Kitchell et al. 1999, Day and Detling, 
1990). With the increasing prevalence of use of artificial reefs in the marine environment for management (Stone 1985, Briones-Fourzan and Lozano Alvarez 2001, Campos and Gamboaa, 2006, Watanuki and Gonzales 2006) and recreational purposes (Leeworthy et al. 2006), the need for greater scientific understanding of both top-down and bottom-up effects of the resulting aggregation and nutrient cycling is of paramount importance. I recommend further experiments of this nature to continue to understand the ecological theory regarding aggregation of marine fauna in natural habitats, as well as application of this understanding in situations where this aggregation is induced. 
0 Taxa absent from quadrat

0.1 Taxa represented by a solitary shoot, $<5 \%$ cover

0.5 Taxa represented by a few $(<5)$ shoots, $<5 \%$ cover

1 Taxa represented by many ( $>5)$ shoots, $<5 \%$ cover

2 Taxa represented by many ( $>5$ ) shoots, $5-25 \%$ cover

3 Taxa represented by many ( $>5$ ) shoots, $25-50 \%$ cover

4 Taxa represented by many ( $>5)$ shoots, $50-75 \%$ cover

5 Taxa represented by many ( $>5)$ shoots, $75-100 \%$ cover

Table 1. Braun Blanquet scoring adjusted for scoring marine macrophyte abundance (Fourqurean 1999). 
D.F.

F-value

p-value

\begin{tabular}{|c|c|c|c|c|}
\hline \multirow{7}{*}{$\begin{array}{c}\text { Fauna } \\
\text { abundance }\end{array}$} & Reef & 12 & 73.62 & $<0.0001$ \\
\hline & Exclosure & 12 & 420.36 & $<0.0001$ \\
\hline & Reef $x$ Exclosure & 12 & 73.62 & $<0.0001$ \\
\hline & Time & 60 & 4.88 & 0.0008 \\
\hline & Exclosure $x$ Time & 60 & 0.58 & 0.8244 \\
\hline & Reef $x$ Time & 60 & 4.88 & 0.0008 \\
\hline & Reef $x$ Exclosure $x$ Time & 60 & 0.58 & 0.8244 \\
\hline \multirow{7}{*}{$\begin{array}{l}\% \text { Organic } \\
\text { matter }\end{array}$} & Reef & 12 & 0.61 & 0.561 \\
\hline & Exclosure & 12 & 0.13 & 0.723 \\
\hline & Reef $x$ Exclosure & 12 & 0.12 & 0.884 \\
\hline & Time & 60 & 191.06 & $<0.0001$ \\
\hline & Exclosure $x$ Time & 60 & 1.21 & 0.304 \\
\hline & Reef $x$ Time & 60 & 7.02 & $<0.0001$ \\
\hline & Reef $x$ Exclosure $x$ Time & 60 & 2.77 & 0.0069 \\
\hline \multirow{7}{*}{$\begin{array}{l}\text { \% Sediment } \\
\text { Nitrogen }\end{array}$} & Reef & 12 & 1.04 & 0.384 \\
\hline & Exclosure & 12 & 1.15 & 0.305 \\
\hline & Reef $x$ Exclosure & 12 & 0.93 & 0.420 \\
\hline & Time & 60 & 1.03 & 0.406 \\
\hline & Exclosure $x$ Time & 60 & 0.99 & 0.465 \\
\hline & Reef $x$ Time & 60 & 0.95 & 0.459 \\
\hline & Reef $x$ Exclosure $x$ Time & 60 & 1.01 & 0.443 \\
\hline \multirow{7}{*}{$\begin{array}{l}\text { \% Sediment } \\
\text { Phosphorus }\end{array}$} & Reef & 12 & 4.89 & 0.028 \\
\hline & Exclosure & 12 & 7.18 & 0.020 \\
\hline & Reef $x$ Exclosure & 12 & 0.11 & 0.898 \\
\hline & Time & 60 & 99.34 & $<0.0001$ \\
\hline & Exclosure $x$ Time & 60 & 3.08 & 0.003 \\
\hline & Reef $x$ Time & 60 & 10.27 & $<0.001$ \\
\hline & Reef $x$ Exclosure $x$ Time & 60 & 1.92 & 0.050 \\
\hline \multirow{7}{*}{$\begin{array}{l}\text { Sediment Chl- } \\
\qquad a\end{array}$} & Reef & 12 & 3.73 & 0.050 \\
\hline & Exclosure & 12 & 2.87 & 0.116 \\
\hline & Reef $x$ Exclosure & 12 & 2.52 & 0.123 \\
\hline & Time & 60 & 45.12 & $<0.0001$ \\
\hline & Exclosure $x$ Time & 60 & 1.45 & 0.181 \\
\hline & Reef $x$ Time & 60 & 0.55 & 0.735 \\
\hline & Reef $x$ Exclosure $x$ Time & 60 & 0.91 & 0.528 \\
\hline \multirow{2}{*}{$\begin{array}{l}\text { Periphyton } \\
\text { Chl- } a\end{array}$} & Reef & 12 & 16.90 & 0.0003 \\
\hline & Exclosure & 12 & 32.13 & 0.0001 \\
\hline
\end{tabular}




\begin{tabular}{|c|c|c|c|c|}
\hline & Reef $x$ Exclosure & 12 & 10.74 & 0.0021 \\
\hline & Time & 60 & 88.09 & $<0.0001$ \\
\hline & Exclosure $x$ Time & 60 & 9.45 & $<0.0001$ \\
\hline & Reef $x$ Time & 60 & 11.73 & $<0.0001$ \\
\hline & Reef $x$ Exclosure $x$ Time & 60 & 7.99 & $<0.0001$ \\
\hline$\%$ Thalassia & Reef & 1 & 8.643 & 0.012 \\
\hline Nitrogen & Exclosure & 2 & 0.323 & 0.730 \\
\hline & Reef $x$ Exclosure & 2 & 0.351 & 0.711 \\
\hline$\%$ Thalassia & Reef & 1 & 2.291 & 0.156 \\
\hline Phosphorus & Exclosure & 2 & 1.147 & 0.350 \\
\hline & Reef $x$ Exclosure & 2 & 0.507 & 0.615 \\
\hline Thalassia & Reef & 1 & 209.660 & $<0.0001$ \\
\hline height & Exclosure & 2 & 48.480 & $<0.0001$ \\
\hline & Reef $x$ Exclosure & 2 & 54.235 & $<0.0001$ \\
\hline
\end{tabular}

Table 2. Results from statistical analyses of response variables. Most response variables were analyzed using repeated measures. Since Thalassia was only collected in the first and last sampling month, a two-way ANOVA was used to test the differences between the two months sampled. SNK tests on Thalassia height revealed that reef and reef with partial exclosure were significantly different to all other treatments $(\mathrm{p}<0.0001)$. 


\section{Difference of Least Square Means}

\begin{tabular}{|c|c|c|c|c|c|c|c|c|c|}
\hline $\begin{array}{l}\text { Resp. } \\
\text { Variable }\end{array}$ & Effect & Reef & Excl & Time & ${ }^{*}$ Reef & ${ }^{*}$ Excl & *Time & Df & Adj P \\
\hline \multirow[t]{4}{*}{ Fauna } & $\begin{array}{l}\text { Excl x } \\
\text { Reef }\end{array}$ & 1 & 1 & & 2 & 1 & & 12 & $<0.0001$ \\
\hline & $\begin{array}{l}\text { Excl x } \\
\text { Reef }\end{array}$ & 1 & 1 & & 1 & 3 & & 12 & $<0.0001$ \\
\hline & $\begin{array}{l}\text { Excl x } \\
\text { Reef }\end{array}$ & 1 & 2 & & 1 & 3 & & 12 & $<0.0001$ \\
\hline & $\begin{array}{l}\text { Reef } \\
x \\
\text { Time }\end{array}$ & 1 & & 1 & 1 & & 6 & 60 & $<0.0001$ \\
\hline \multirow[t]{4}{*}{$\begin{array}{l}\text { Organic } \\
\text { Matter }\end{array}$} & $\begin{array}{l}\text { Reef } \\
x \\
\text { Time }\end{array}$ & 1 & & 1 & 1 & & 6 & 60 & $<0.0001$ \\
\hline & $\begin{array}{l}\text { Reef } \\
x \\
\text { Time }\end{array}$ & 1 & & 1 & 1 & & 5 & 60 & 0.0003 \\
\hline & $\begin{array}{l}\text { Reef } \\
x \text { Excl } \\
x \\
\text { Time }\end{array}$ & 1 & 1 & 1 & 1 & 1 & 5 & 60 & $<0.0001$ \\
\hline & $\begin{array}{l}\text { Reef } \\
\mathrm{x} \text { Excl } \\
\mathrm{x} \\
\text { Time }\end{array}$ & 1 & 2 & 1 & 1 & 2 & 6 & 60 & $<0.0001$ \\
\hline \multirow[t]{2}{*}{$\begin{array}{l}\text { Sediment } \\
\text { Phosphorus }\end{array}$} & $\begin{array}{l}\text { Reef } \\
x \text { Excl } \\
x \\
\text { Time }\end{array}$ & 1 & 1 & 1 & 1 & 1 & 6 & 60 & $<0.0001$ \\
\hline & $\begin{array}{l}\text { Reef } \\
x \text { Excl } \\
x \\
\text { Time }\end{array}$ & 1 & 2 & 1 & 1 & 2 & 6 & 60 & $<0.0001$ \\
\hline \multirow[t]{2}{*}{$\begin{array}{l}\text { Periphyton } \\
\text { Chl- } a\end{array}$} & $\begin{array}{l}\text { Reef } \\
x \text { Excl } \\
x \\
\text { Time }\end{array}$ & 1 & 3 & 2 & 1 & 3 & 4 & 36 & $<0.0001$ \\
\hline & $\begin{array}{l}\text { Reef } \\
\mathrm{x} \text { Excl } \\
\mathrm{x} \\
\text { Time }\end{array}$ & 1 & 1 & 1 & 1 & 1 & 4 & 36 & $<0.0001$ \\
\hline
\end{tabular}

Table 3. Differences of least mean squares of significant treatment combinations 
Periphytometer $C h l-a$ ug/ml

\begin{tabular}{|c|c|c|c|c|}
\hline & July '05 & Nov '05 & March '06 & May '06 \\
\hline Reef & $\begin{array}{l}13.127 \pm \\
5.137\end{array}$ & $22.297 \pm 22.591$ & $23.071 \pm 19.603$ & $11.950 \pm 9.189$ \\
\hline Reef w/ reef & $\begin{array}{l}18.413 \pm \\
7.621\end{array}$ & $25.933 \pm 9.088$ & $5.066 \pm 1.660$ & $26.144 \pm 12.530$ \\
\hline $\begin{array}{l}\text { Reef w/ } \\
\text { exclosure }\end{array}$ & $\begin{array}{l}18.440 \pm \\
11.179\end{array}$ & $\begin{array}{l}117.947 \pm \\
12.120\end{array}$ & $30.100 \pm 19.705$ & $28.616 \pm 12.838$ \\
\hline Seagrass & $\begin{array}{l}13.657 \pm \\
0.559\end{array}$ & $74.493 \pm 22.924$ & $54.406 \pm 8.773$ & $13.024 \pm 8.550$ \\
\hline $\begin{array}{l}\text { Seagras w/ } \\
\text { reef }\end{array}$ & $\begin{array}{l}24.923 \pm \\
14.894\end{array}$ & $\begin{array}{l}115.497 \pm \\
26.365\end{array}$ & $35.533 \pm 4.976$ & $15.796 \pm 9.609$ \\
\hline $\begin{array}{l}\text { Seagrass w/ } \\
\text { exclosure }\end{array}$ & $\begin{array}{l}19.420 \pm \\
11.564\end{array}$ & $97.967 \pm 13.296$ & $36.691 \pm 2.829$ & $33.124 \pm 1.762$ \\
\hline
\end{tabular}

Table 4. Values represent chlorophyll- $a$ concentrations for each treatment over the sampling period. Samplers were first put out in May and recollected during the July sampling event. There were significantly higher concentrations of periphyton chlorophyll at exclosure treatments at the end of the sampling periods $(\mathrm{p}<0.022)$. Treatments with no exclosure showed decreases in chlorophyll concentrations compared to other treatments $(\mathrm{p}<0.0001)$. All values mean \pm standard deviation 


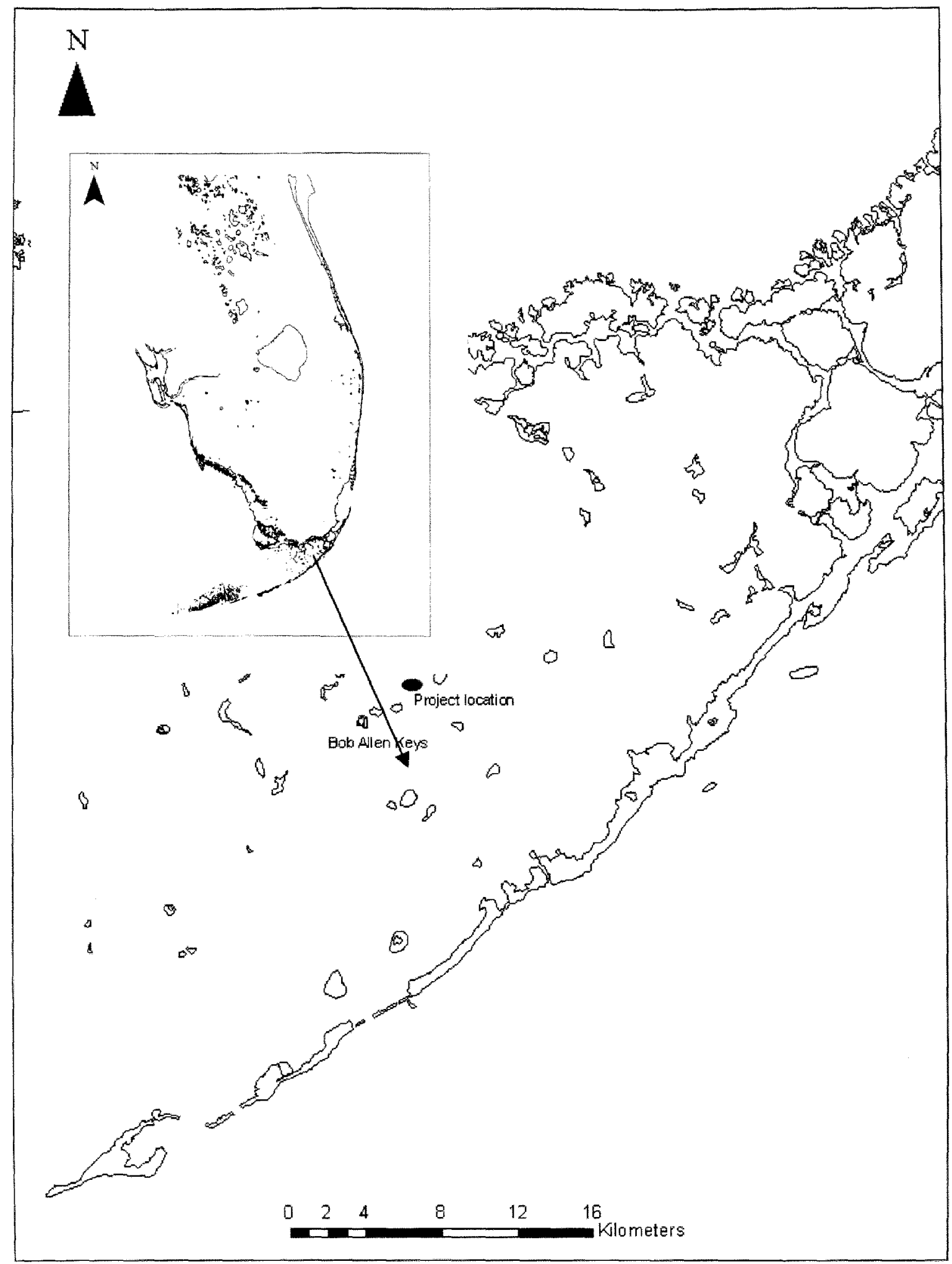

Figure 1. Map of central portion of Florida Bay with Florida state inset. Artificial reefs were located to the northeast of Bob Allen Keys. 


\section{Experimental Layout}

North

\begin{tabular}{|c|c|c|}
\hline $\begin{array}{l}\text { Reef w/ partial exclosure } \\
\text { (RPE1) } \\
\text { N } 2502.095 \\
\text { W080 } 39.471\end{array}$ & $\begin{array}{l}\text { Reef (RNE2) } \\
\text { N } 2502.095 \\
\text { W080 39.461 }\end{array}$ & $\begin{array}{l}\text { Seagrass w/ partial } \\
\text { exclosure (SPE3) } \\
\text { N } 2502.095 \\
\text { W080 39.451 }\end{array}$ \\
\hline $\begin{array}{l}\text { Seagrass w/ full exclosure } \\
\text { (SFE1) }\end{array}$ & $\begin{array}{l}\text { Reef w/ partial exclosure } \\
\text { (RPE2) }\end{array}$ & $\begin{array}{l}\text { Reef w/ full exclosure } \\
\text { (RFE3) }\end{array}$ \\
\hline $\begin{array}{l}\text { N } 2502.085 \\
\text { W080 } 39.471\end{array}$ & $\begin{array}{l}\text { N } 2502.085 \\
\text { W080 } 39.461\end{array}$ & $\begin{array}{l}\text { N } 2502.085 \\
\text { W080 } 39.451\end{array}$ \\
\hline $\begin{array}{l}\text { Reef w/ full exclosure } \\
\text { (RFE1) } \\
\text { N } 2502.075 \\
\text { W080 39.471 }\end{array}$ & $\begin{array}{l}\text { Seagrass w/ partial } \\
\text { exclosure (SPE2) } \\
\text { N } 2502.075 \\
\text { W080 39.461 }\end{array}$ & $\begin{array}{l}\text { Seagrass (SNE3) } \\
\text { N } 2502.075 \\
\text { W080 39.451 }\end{array}$ \\
\hline $\begin{array}{l}\text { Seagrass (SNE1) } \\
\text { N } 2502.065 \\
\text { W080 } 39.471\end{array}$ & $\begin{array}{l}\text { Seagrass w/ full exclosure } \\
\text { (SFE2) } \\
\text { N } 2502.065 \\
\text { W080 39.461 }\end{array}$ & $\begin{array}{l}\text { Reef (RNE3) } \\
\text { N } 2502.065 \\
\text { W080 39.451 }\end{array}$ \\
\hline $\begin{array}{l}\text { Seagrass w/ partial } \\
\text { exclosure (SPE1) } \\
\text { N } 2502.055 \\
\text { W080 } 39.471\end{array}$ & $\begin{array}{l}\text { Reef w/ full exclosure } \\
\text { (RFE2) } \\
\text { N } 2502.055 \\
\text { W080 39.461 }\end{array}$ & $\begin{array}{l}\text { Reef w/ partial exclosure } \\
\text { (RPE3) } \\
\text { N } 2502.055 \\
\text { W080 39.451 }\end{array}$ \\
\hline $\begin{array}{l}\text { Reef (RNE1) } \\
\text { N } 2502.045 \\
\text { W080 39.471 }\end{array}$ & $\begin{array}{l}\text { Seagrass (SNE2) } \\
\text { N } 2502.045 \\
\text { W080 } 39.461\end{array}$ & $\begin{array}{l}\text { Seagrass w/ full exclosure } \\
\text { (SFE3) } \\
\text { N } 2502.045 \\
\text { W080 39.451 }\end{array}$ \\
\hline
\end{tabular}

Figure 2. Layout of treatments and replicates in the field.

$\mathrm{RNE}=$ Reef $\mathrm{w} /$ no exclosure, $\mathrm{RPE}=$ Reef $\mathrm{w} /$ partial exclosure, $\mathrm{RFE}=\mathrm{Reef} \mathrm{w} /$ full exclosure, $\mathrm{SNE}=$ Seagrass $\mathrm{w} /$ no exclosure, $\mathrm{SPE}=$ Seagrass $\mathrm{w} /$ partial exclosure, $\mathrm{SFE}=$ Seagrass $w /$ full exclosure 


\section{Faunal Abundance}

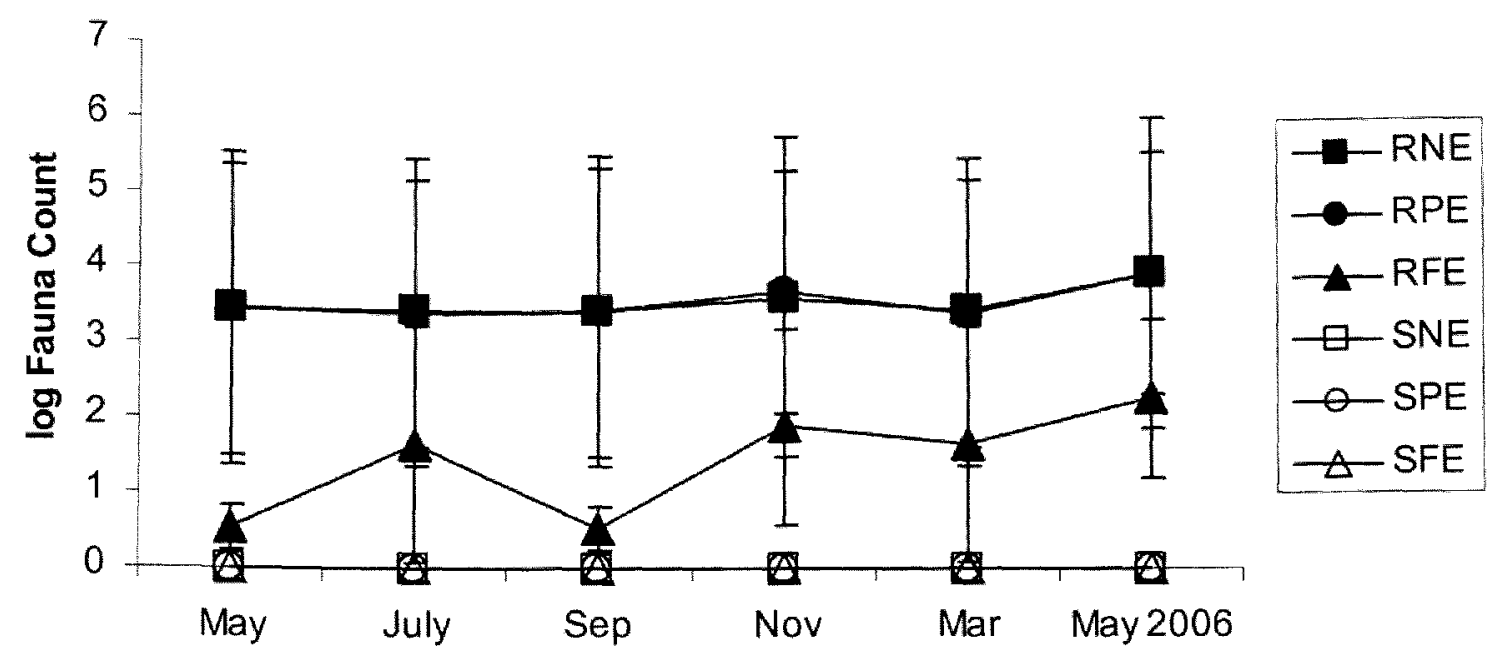

Figure 3. Log transformed faunal abundances for all treatments in May 2006. There were significantly higher fish abundances at reefs and reefs with reef treatments. Fauna abundance showed no significant variation among treatment types over the year-long sampling period. Graph represents typical abundances at reefs and corresponding controls. Error bars represent standard error. 


\section{Organic Matter Concentration}

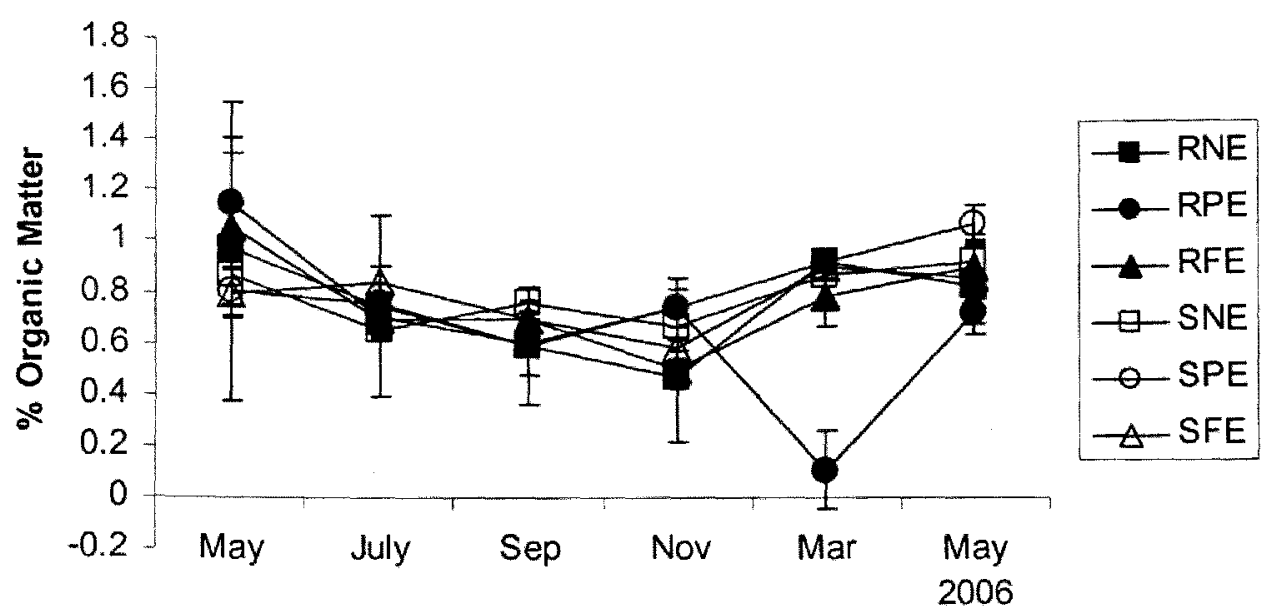

Nitrogen Concentration

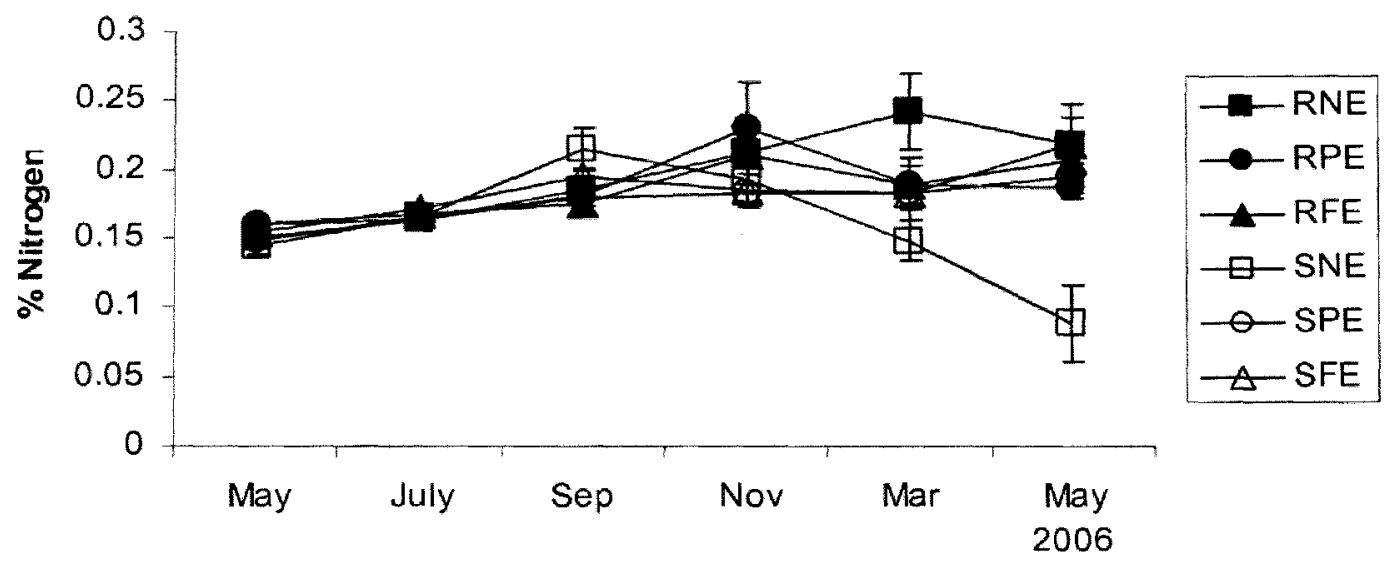

Phosphorus concentration

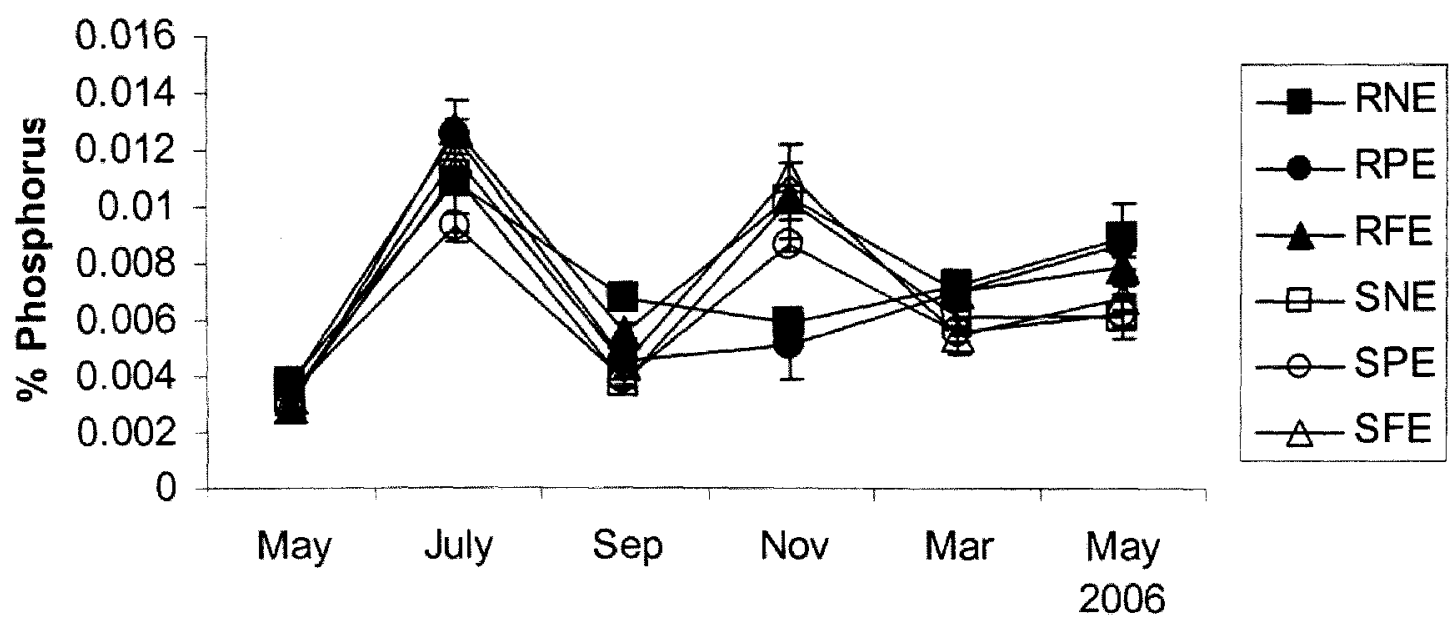

Month

Figure 4. Graphs represent changes in nutrient concentrations throughout the sample period between reef and no reef treatments. Error bars represent standard error. $(\mathrm{NE}=$ no exclosure, $\mathrm{PE}=$ partial exclosure, $\mathrm{FE}=$ full exclosure $)$ 

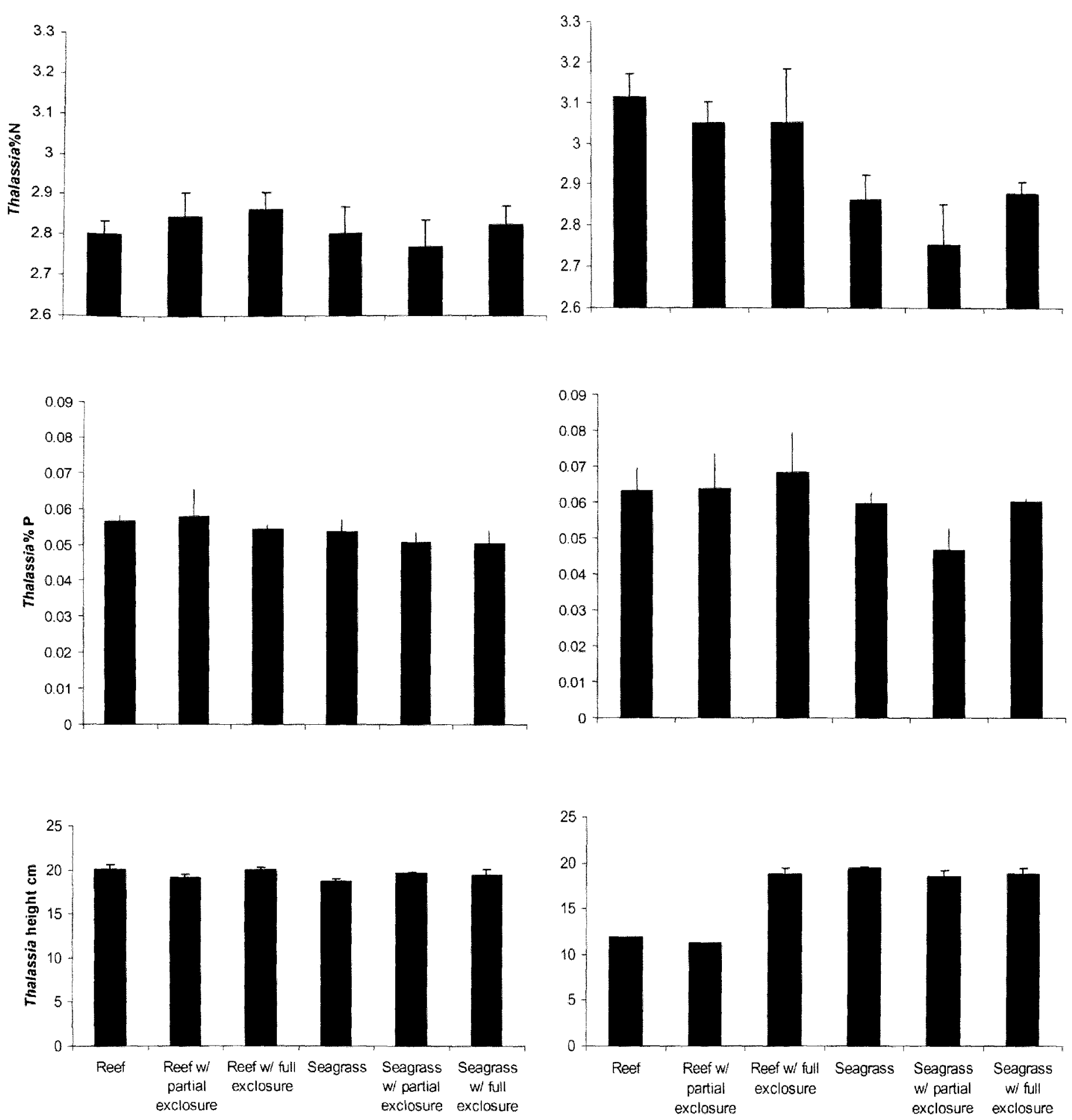

Figure 5. Comparison of Thalassia nutrients and height between May 2005 and May 2006. Error bars represent standard error. 


\section{Sediment Chlorophyll-a concentration}

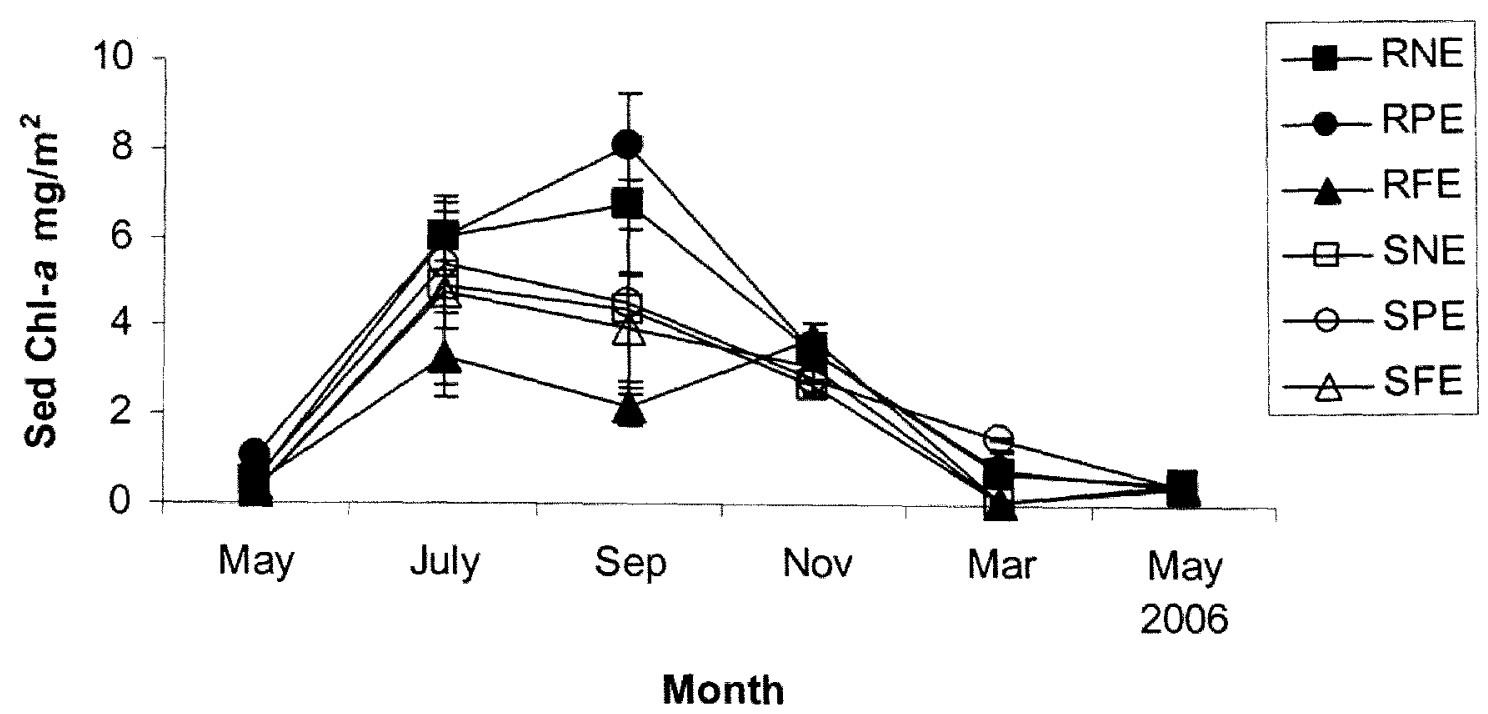

Figure 6. Sediment chlorophyll- $a$ concentrations all treatments over the sampling period. Error bars represent standard error. 


\section{References}

Alevizon, W. 2002. Enhanced seagrass growth and fish aggregations around Bahamian patch reefs: the case for a functional connection. Bulletin of Marine Science. 70: 957-966

Allaway, W.G. and A.E. Ashford. 1984. Nutrient input seabirds to the forest on a coral island of the Great Barrier Reef. Marine Ecology Progress Series. 19:297-298

Armitage, A.R., T.A. Frankovich and J.W. Fourqurean. 2006. Variable responses within epiphytic and benthic microalgal communities to nutrient enrichment. Hydrobiologia. 569:423-435.

Bildstein, K.L., E. Blood and P. Frederick. 1992. The relative importance of biotic and abiotic vectors in nutrient transport. Estuaries. 15:147-157.

Bortone, S.A. 2006. A perspective of artificial reef research: the past, present, and future. Bulletin of Marine Science. 78(1):1-8

Bosman, A.L., Du Toit, J.T., Hockey, P.A.R. and G.M. Branch. 1986. A field experiment demonstrating influence of seabird guano on intertidal primary production. Estuarine, Coastal and Shelf Science. 23:283-294

Briones-Fourzan, P and E. Lozano-Alvarez. 2001. Effects of artificial shelters (casitas) on the abundance and biomass of juvenile spiny lobsters Panulirus argus in a habitatlimited tropical reef lagoon. Marine Ecology Progress Series. 221:221-232

Campos, J.A. and C. Gamboaa. 1989. An artificial tire-reef in a tropical marine system: a management tool. Bulletin of Marine Science. 44:757-766

Davis, G.E. 1985. Artificial reefs to mitigate marina construction impacts on spiny lobster, Panulirus argus. Bulletin of Marine Science. 37(1):151-156

Day, T.A. and J.K. Detling. 1990. Grassland patch dynamics and herbivore grazing preference following urine deposition. Ecology. 71: 180-188.

Dennison, W.C. and R.S. Albarte. 1982. Photosynthetic responses of Zostera marina L. (eelgrass) to in situ manipulations of light intensity. Oecologia. 55:137-144.

Durbin, A.G., Nixon, S.W. and C.A. Oviatt. 1979. Effects of the spawning migration of the Alewife, Alosa Pseudoharengus, on freshwater ecosystems. Ecology. 60:8-17

Fourqurean, J.W. and M.B. Robblee. 1999. Florida Bay: A history of recent ecological changes. Estuaries. 22:345-357. 
Fourqurean, J.W. and J.C. Zieman. Phosphorus limitation of primary production in Florida Bay: Evidence from C:N:P ratios of the dominant seagrass. Limnology and Oceanography. 37:162-171

Fouqurean J.W., Powell, J.W., Kenworthy, G.V.N. and J.C. Zieman. 1995. The effects of long-term manipulation of nutrient supply on competition between the seagrasses Thalassia testudinum and Halodule wrightii in Florida Bay. Oikos. 72:349-358

Fourqurean J.W., J.C. Zieman and G.V.N. Powell. 1992. Phosphorus limitation of primary production in Florida Bay: Evidence from C:N:P ratios of the dominant seagrass Thalassia testudinum. Limnology and Oceanography 37: 162-171.

Fourqurean, J. W., J. C. Zieman, and G. V. N. Powell. 1992b. Relationships between porewater nutrients and seagrasses in a subtropical carbonate environment. Marine Biology 114: 57-65.

Fourqurean, J.W., A. Willsie, C.D. Rose and L.M. Rutten. 1999. Spatial and temporal pattern in seagrass community composition and productivity in south Florida. Marine Biology 138:341-354.

Frank, D.A., and S.J. McNaughton. 1992. The ecology of plants, large mammalian herbivores, and drought in Yellowstone National Park. Ecology. 73:2043-2058.

Frouz, J., Holec, M. and J. Kalcik. 2003. The effect of Lasius niger (Hymenoptera, Formicidae) ant nest on selected soil chemical properties. Pedobiologia. 47:205-212.

Gallagher, JL., Kibby, HV and KW Shirvin. 1984. Detritus processing and mineral cycling in seagrass (Zostera) litter in an Oregon salt marsh. Aquatic Botany. 20:97-108

Geesey, G.G., Alexander, G.V., Bray R.N. and A.C. Miller. 1984. Fish fecal pellets are a source of minerals for inshore reef communities. Marine Ecology Progress Series. 15:1925

Gende, S.M., Edwards, R.T., Willson, M.F. and M.S. Wipfli. 2002. Pacific salmon in aquatic and terrestrial ecosystems. BioScience. 52(10):917-928.

Hayes, J.P. and J.W. Caslick. 1984. Nutrient deposition in cattail stands by communally roosting blackbirds and starlings. The American Midland Naturalist. 112 (2): 320-331

Joblin, K.N. 1981. Effect of urine on the elemental composition of spring regrowth herbage in a ryegrass pasture. New Zealand Journal of Agricultural Research. 24:293297

Kitchell, J.F., R.V. O’Neill, D. Ibb, G.W. Gallepp, S.M. Bartell, J.F. Koonce and B.S. Ausmus. 1979. Consumer regulation of nutrient cycling. Bioscience 29:1 28-34. 
Kitchell, J.F., Schindler, D.E., Herwig, B.R., Post, D.M., Olson, M.H. and Oldham, M. 1999. Nutrient cycling at the landscape scale: The role of diel foraging migrations by geese at the Bosque del Apache National Wildlife Refuge, New Mexico. Limnology and Oceanography. 44:828-836

Lal, R. 1998. Effects of microfauna on soil properties in tropical ecosystems. Agriculture, ecosystems \& environment. 24: 101-116.

Leeworthy, V.R., Maher, T. and E.A. Stone. 2006. Can artificial reefs alter user pressure on adjacent natural reefs? Bulletin of Marine Science. 78:29-37

Lindeboom, H.J. 1984. The nitrogen pathway in a penguin rookery. Ecology. 65: 269277.

Lock, J.M. 1971. The effects of hippopotamus grazing on grasslands. The Journal of Ecology 60:445-467.

Lugo, A.E., Farnworth, E.G., Pool, D., Jerez, P. and G. Kaufman. 1973. The impact of the leaf cutter ant Atta Colombica on the energy flow of a tropical wet forest. Ecology. 54: $1292-1301$.

McColl, J.G. and J. Burger. 1976. Chemical inputs by a colony of Franklin's Gulls nesting in cattails. American Midland Naturalist. 96(2):270-280.

Meyer, J.L. and E.T. Schultz. 1985. Migrating haemulid dishes as a source of nutrients and organic matter on coral reefs. Limnology and Oceanography. 30(1):146-156.

Meyer, J.L., Schultz, E.T. and G.S. Helfman. 1983. Fish schools: an asset to corals. Science. 220:1047-1049.

Ogden, J.C. and P.R. Ehrlich. 1977. The behavior of heterotypic resting schools of juvenile grunts (Pomadasyidae). Marine Biology. 273-280

Ogden, J.C. and J.P. Ebersole. 1981. Scale and community reef of coral reef fishes: a long-term study of a large artificial reef. Marine Ecology Progress Series. 97-103.

Post, D.M., Taylor, J.P., Kitchell, J.F., Olson, M.H., Schindler, D.E. and B.R. Herwig. The role of migratory waterfowl as nutrient vectors in a managed wetland. Conservation Biology. 12:910-920.

Powell, G.V.N., Fourqurean, J.W., Judson Kenworthy, W. and J.C. Zieman . 1991. Bird colonies cause seagrass enrichment in a subtropical estuary: observational and experimental evidence. Estuarine, Coastal and Shelf Science. 32:567-579. 
Powell, G.V.N., Judson Kenworthy, W. and J.W. Fourqurean. 1989. Experimental evidence for nutrient limitation of seagrass growth in a tropical estuary with restricted circulation. Bulletin of Marine Science. 44:324-340

Randall, J.E. 1963. An analysis of the fish populations of artificial and natural reefs in the Virgin Islands. Caribbean Journal of Science. 32:567-579.

Rothans, J.C. and A.C. Miller. 1991. A link between biologically imported particulate organic nutrients and the detritus food web in reef communities. Marine Biology. 110:145-150.

Stone, R.B. 1985. Draft national artificial reef plan. NOAA/NMFS. Washington, D.C. $85 \mathrm{pp}$.

Thayer, G.W., and A.J. Chester. 1989. Distribution and abundance of fishes among basin and channel habitats in Florida Bay. Bulletin of Marine Science 44:200-219

Wagner, D. 1997. The influence of ant nests on Acacia seed production, herbivory and soil nutrients. Journal of Ecology. 85: 83-93.

Wagner, D. and J.B. Jones. 2004. The contribution of harvester ant nests, Pogonomyrex rugosus (Hymnoptera, Formicadae), to soil nutrient stocks and microbial biomass in the Mojave Desert. Environmental Entomology. 33(3):599-607.

Watanuki, N. and B.J. Gonzales. 2006. The potential of artificial reefs as fisheries management tools in developing countries. Bulletin of Marine Science. 78:9-19

Wiegert, R.G., and D.F. Owen. 1971. Trophic reef, available resources and population density in terrestrial vs. aquatic systems. Journal of Theoretical Biology. 30:69-81.

Youngbluth, M.J. 1982. Utilization of a fecal mass as food by the pelagic mysis larva of the Penaeid Shrimp (Solenocera atlantidis). Marine Biology. 66:47-51.

Zieman, J.C., Fourqurean, J.W., 1985. The distribution and abundance of benthic vegetation in Florida Bay, Everglades National Park. Final Report contract \# CX5280-22204. South Florida Research Center, National Park Service, Homestead, Florida.

Zieman, J.C., J.W. Fouqurean and R.L. Iverson. 1989. Distribution, abundance and productivity of seagrasses and macroalgae in Florida Bay. Bulletin of Marine Science 44: 292-311. 